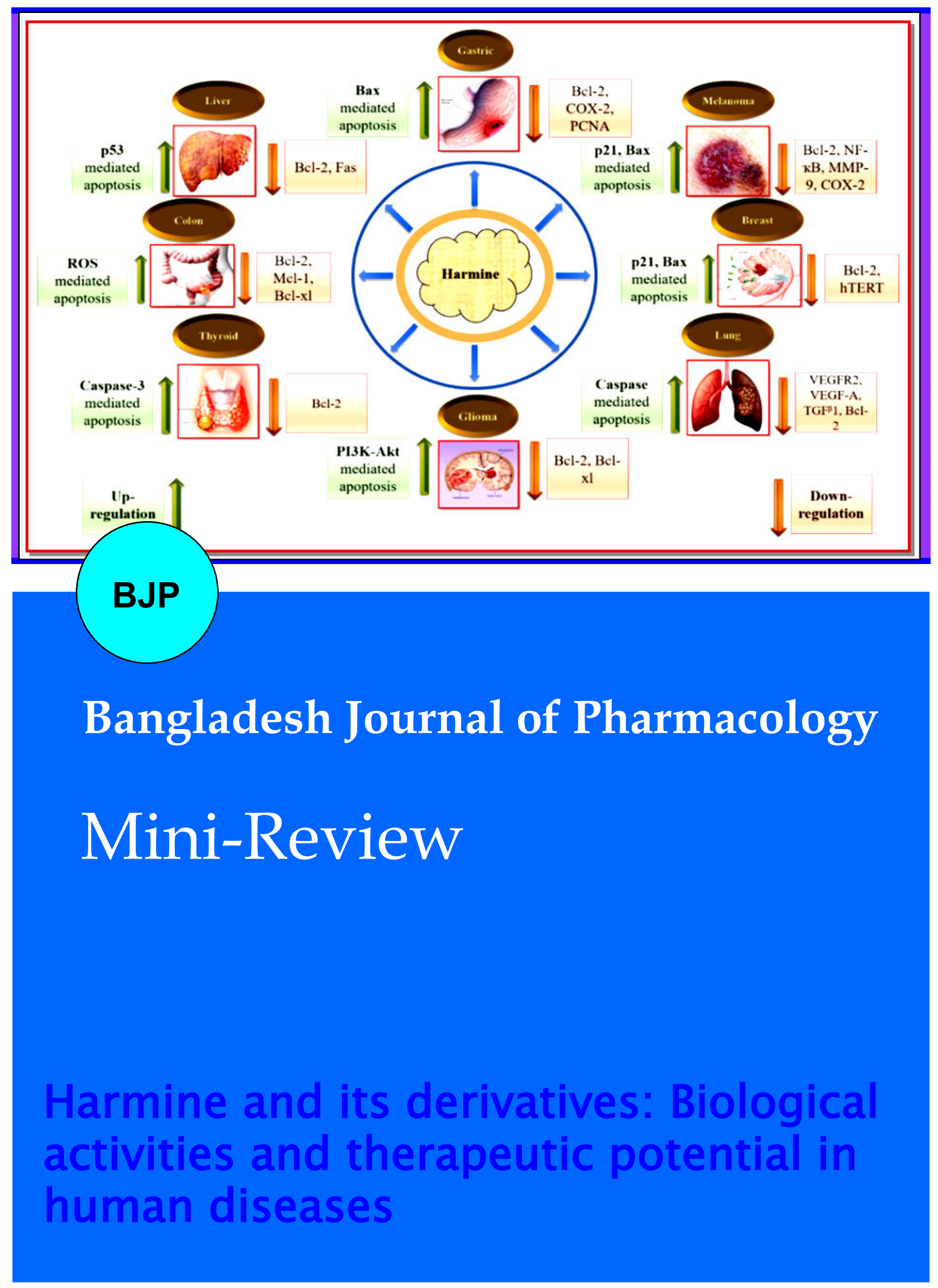


Abstracted/indexed in Academic Search Complete, Agroforestry Abstracts, Asia Journals Online, Bangladesh Journals Online, Biological Abstracts, BIOSIS Previews, CAB Abstracts, Current Abstracts, Directory of Open Access Journals, EMBASE/Excerpta Medica, Google Scholar, HINARI (WHO), International Pharmaceutical Abstracts, Open J-gate, Science Citation Index Expanded, SCOPUS and Social Sciences Citation Index

ISSN: $1991-0088$

\title{
Harmine and its derivatives: Biological activities and therapeutic potential in human diseases
}

\author{
Maria Javeed", Azhar Rasul', Ghulam Hussain², Farhat Jabeen', Bilal Rasool', Nusrat \\ Shafiq ${ }^{3}$, Ammara Riaz ${ }^{1}$, Ghazala Kaukab ${ }^{1}$ and Muhammad Ali ${ }^{1}$
}

${ }^{1}$ Department of Zoology, Faculty of Life Sciences, Government College University, Faisalabad, 38000 Pakistan; ${ }^{2}$ Department of Physiology, Faculty of Life Sciences, Government College University, Faisalabad, 38000 Pakistan; ${ }^{3}$ Department of Chemistry, Government College Women University, Faisalabad 38000, Pakistan.

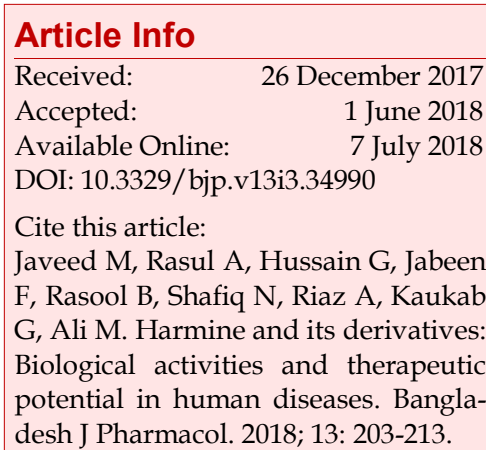

\begin{abstract}
This review article aims to provide an update on the sources, pharmacological and biological profile of a $\beta$-carboline alkaloid, harmine which is a major bioactive component of various plants mainly Peganum harmala. Harmine's wide range of pharmacological properties has been welldocumented as anti-cancer, anti-inflammatory, anti-oxidant, neuroprotective, anti-depressant, and antimicrobial. Although reported data suggests a multifunctional pharmacological role of harmine but farther experimentation on its molecular mechanism of action, synthetic chemistry approaches, and preclinical studies are yet obligatory to fully uncover its pharmacological efficacy.
\end{abstract}

\section{Introduction}

Natural products have served humanity as a fundamental source of medicine throughout the history of civilization. The term natural product is usually defined as chemical entities that are mainly originated from the living species such as microorganisms, plants, terrestrial vertebrates, marine organisms, and invertebrates (Rasul et al., 2013). Plants offer an extensive reservoir of natural products providing a far-reaching diversity of novel chemical entities in drug industries (Newman et al., 2003).

Plants have established the basis of refined traditional medicinal systems including Chinese, Unani, Ayurvedic, and some others. These traditional systems have a great potential regarding the discovery of many beneficial drugs (Gurib-Fakim, 2006). Since past decades, natural products have been an affluent source of many chemical entities for drug discovery (Harvey et al., 2015). To date, $61 \%$ anti-cancer agents and approximately $49 \%$ anti-infective compounds are directly inspired from nature (Luo et al., 2014).
Alkaloids have been recently described as the most significant group of natural products with basic nitrogen atoms, playing an important role in the ecological aspects of organisms (Bouayad et al., 2012). Additionally, $\beta$-carbolines are the major class of alkaloids with a tricyclic pyrido[3,4-b]indole ring (Filali et al., 2015). They have been proved as natural constituents of human body fluids and tissues. They also display a wide range of behavioral, psychopharmacological, and biochemical effects in both humans and animals (Patel et al., 2012).

Harmine (7-methoxy-1-methyl-9H-pyrido[3,4-b]indole), a naturally existing $\beta$-carboline alkaloid (Filali et al., 2015) has been known to possess numerous biological and pharmacological activities prescribed as anti-cancer (Shabani et al., 2015), anti-microbial (Salman et al., 2016), anti-oxidant (Choi et al., 2004), anti-inflammatory (Hara et al., 2013), anti-depressant (Hamid et al., 2017) and neuroprotective (Herraiz, 2012). Of all $\beta$-carboline groups, harmine and its derivatives have potential pharmacological value (Zhao et al., 2011; Arora et al., 2013; Li et al., 2015). 


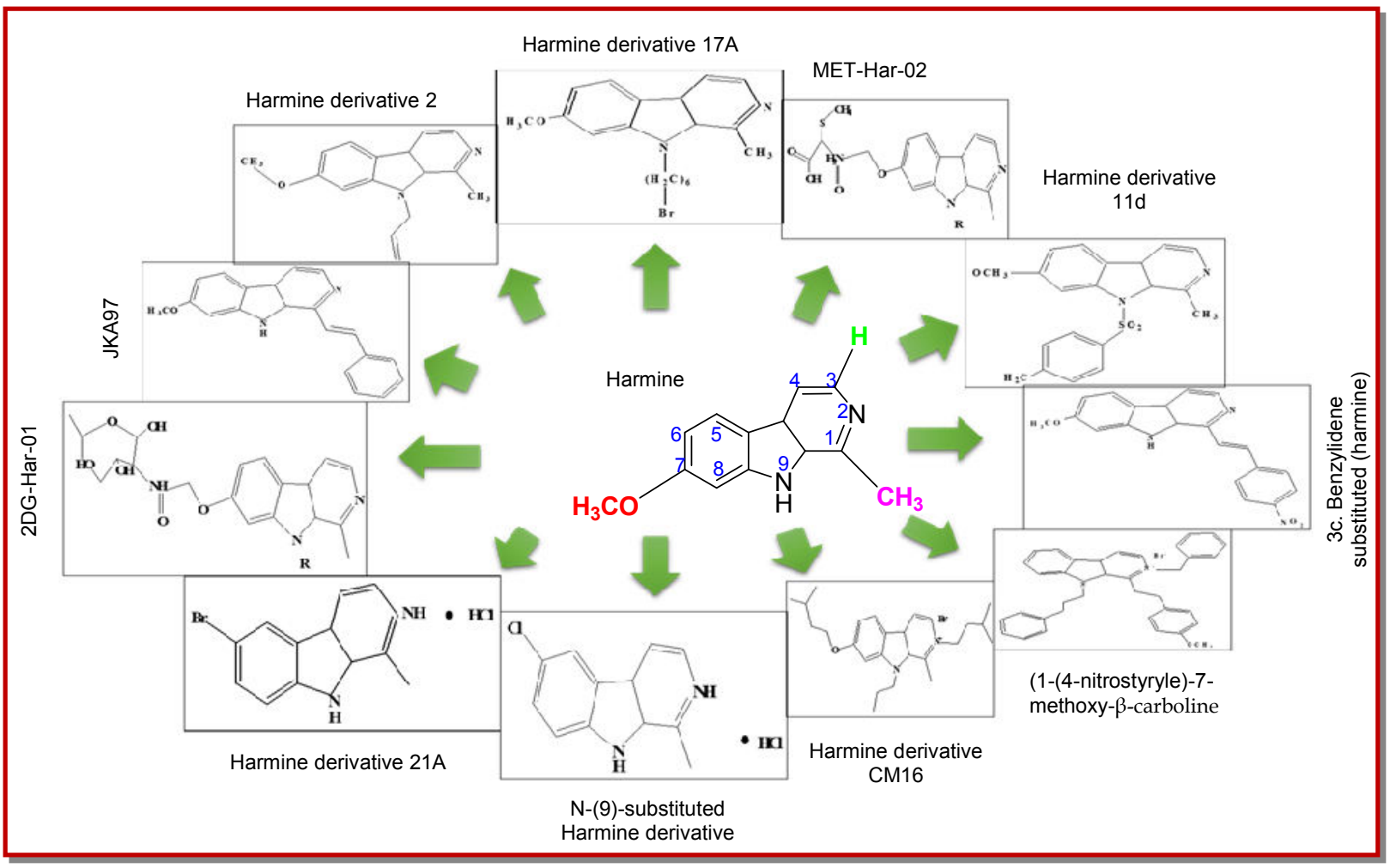

Figure 1: Hermine and its derivatives

This review will emphasize the most recent researches on harmine focusing on its pharmacological and biological properties.

\section{Structure Activity Relationship}

Harmine $\left(\mathrm{C}_{13} \mathrm{H}_{12} \mathrm{ON}_{2}\right)$ is commonly distributed among the animals, marine creatures, plants, and insects (Zhang et al., 2015). Harmine derivatives are gifted with pharmacological profiles (Zhang et al., 2016). Chemical structures of biologically active harmine and its derivatives are represented in Figure 1.

Structure-activity relationship of harmine derivatives has been established by TD-DFT study (Lamchouri et al., 2013) and this study showed that position-3 and 9 played a crucial role in antitumor as well as neurotoxicity of harmine derivatives. Structure activity relationship analysis indicated that replacement of proton presents at position-9 with short alkyl or aryl group increased the cytotoxicity while replacement of proton presents at position-3 with long alkyl or aryl group reduced the antitumor activity. Without any substitution of the proton at position-3 in harmine derivatives led to enhanced antitumor activity. SAR analysis demonstrated that by introducing alkoxy substituents into position-7 of harmine led to enhanced cytotoxic activities, the length of alkoxy chain affected both cytotoxicity and cell line specificity, N9-alkylated harmine derivatives displayed specific cytotoxic effects,
N2-alkylated. Furthermore, SARs studies suggested that substitution of proton of position-9 of harmine enhanced the antitumor activity, 7-methoxy of harmine very important in determining the neurotoxic effects, replacement of methoxy at position-7 with a bulky alkoxy group led to eliminating neurotoxic effects and enhanced antitumor activity (Cao et al., 2013).

In comparison to harmine, the derivatives showed more antitumor potential e.g. 2DG-Har-01 and MET-Har-02 showed more antitumor activity and cell safety as compared to harmine due to the modification of methoxy at position-7 with oxime derivatives. Similarly, JKA97 (methoxy-1-styryl-9H-pyrid-[3,4-b]-indole) showed greater antitumor activity against MCF7, MDAMB-468 and MCF7p53kD cell lines than harmine (Luo et al., 2008). Similarly, 17A and 21A, two harmine derivatives acting as anti-malarial agents. These were found more active as compared to chloroquine and artemisinin due to the substitution of halogens (Bayih et al., 2016).

Structure-activity relationship of N-9 substituted harmine analog $11 \mathrm{~d}$ demonstrated that by the introduction of a haloalkyl or benzene-sulfonyl group in the N9position of harmine could significantly increase the anticancer activity (Du et al., 2016). Harmine derivative 2 and HRMS (harmine derive isoxazole) acting as antiAlzheimer, anti-cancer, and anti-inflammatory agent showed good activity due to N9-substitution (Filali et al., 2015). 
Table I

Plants containing harmine with their biological functions

\begin{tabular}{|llllll|}
\hline Botanical name & English name & Parts used & Disease/function & References \\
\hline $\begin{array}{l}\text { Andrographis paniculata } \\
\text { Banisteriopsis caapi }\end{array}$ & Green chirayta & Ryahuasca vine & Stalk & $\begin{array}{l}\text { Neuroprotective, cognitive enhanc- } \\
\text { ing property }\end{array}$ & $\begin{array}{l}\text { Dos Santos and Hallak, } \\
2017\end{array}$ \\
Kochia scoparia & Mexican fireweed & - & Reduction in survival and weight & Westcott et al., 1992 \\
$\begin{array}{l}\text { Oxalis tuberosa } \\
\text { Passiflora incarnata }\end{array}$ & Wood sorrel & Root & Anti-microbial & Bais et al., 2003 \\
Passiflora caerulea & Blue passion flower & - & Anti-leishmanial, anti-HIV, & Fyre and Haustein, 2007 \\
Peganum harmala & Wild rue & - & vasorelaxant & Fyre and Haustein, 2007 \\
Peganum multisectum & African rue & Seed & Anti-proliferative & Cao et al., 2013; Filali et \\
Peganum nigellastrum & Bunge & - & - & al., 2015; Li et al., 2017 \\
\hline
\end{tabular}

Moreover, in vivo and in vitro results demonstrated that substitutions at the position-2, 7 and 9 of harmine led to excellent enhancement in antitumor activity and remarkable reduction in the adverse effects of the drugs because the structural modification at the said positions results in reduced uptake of drug by normal cells and increase the cancer cell specificity (Li et al., 2015).

\section{Plant Sources}

Harmine was first discovered and isolated from the Peganum harmala which is generally utilized as potent herbal medicine due to its abortifacient, emmenagogue, hallucinogenic, lactagogue, and hypothermic properties (Filali et al., 2015). The seed extracts of P. harmala have been traditionally used in Northwest China to cure malaria and alimentary tract cancers for hundreds of years (Cao et al., 2013). P. harmala is a perennial herbaceous plant originally of family Zygophyllaceae but has been recently updated as a member of family Nitrariaceae (Filali et al., 2015). Besides P. harmala, harmine was identified in P. nigellastrum (Ma et al., 2000), and P. multisectum (Liu, 2011).

Harmine was also isolated from the roots and leaves of A. paniculata. It is useful in Chinese Traditional Medicine as an anti-code for snakebite, and to treat dysentery, dyspepsia, malaria, influenza, and respiratory diseases (Kurzawa et al., 2015). Moreover, the stalks of $B$. caapi vine (Dos Santos and Hallak, 2017), and the roots of O. tuberosa (Bais et al., 2003) are found to be a rich source of harmine. Quantitative analysis on harmine showed that it is present in major quantity in $P$. caerulea while in minor quantity in $P$. incarnata (Fyre and Haustein, 2007).

\section{Extraction and Method of Estimation}

Harmine has been extracted by chromatography on silica gel (Ma et al., 2000; Liu, 2011; Filali et al., 2015). It is detected by UPLC/HPLC (Zhao et al., 2011; Bensalem et al., 2014; Li et al., 2017), HPLC-DAD, GC-MS and LC-MS/MS (Kurzawa et al., 2015). Shoots, untransformed roots and leaves of Oxalis tuberosa were extracted in methanol to measure harmine. The experiment proved that quantity of harmine was higher in shoots when compared with leaves and roots (Bais et al., 2003).

JKA97 (methoxy-1-styryl-9H-pyrido-[3,4-b]-indole), a derivative of harmine was identified by HPLC and MS analysis (Yang et al., 2012).

\section{Biological Activities}

The biologically active compound harmine has been demonstrated for its broad spectrum of pharmacological and biological traits such as anticancer, anti-microbial, anti-oxidant, neuroprotective, anti-inflammatory, and anti-depressant (Figure 2). Several in vitro and in vivo investigations have elucidated its medicinal characteristics and mechanism of actions.

\section{Anti-cancer activity}

Programmed cell death or apoptosis is a natural process of eliminating old cells from our body. Approximately all the anti-cancer agents stimulate apoptosis to remove malignant cells. Nevertheless, in cancer, de-regulation of signaling pathways provide gateway towards cellular proliferation which is uncontrolled resulting in the survival of tumor, cancer recurrence and therapeutic resistance (Mohammad et al., 2015). Previous investiga- 


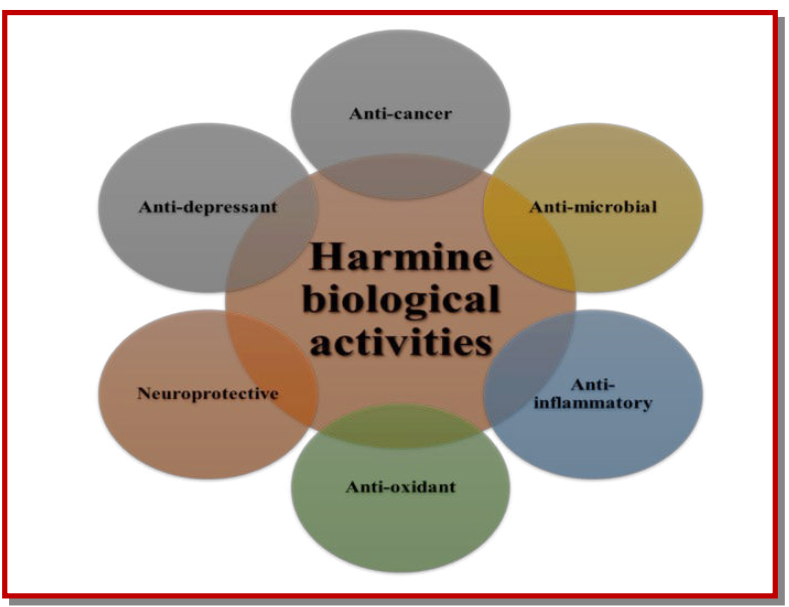

Figure 2: Biological activities of harmine

tions have reported that AMPK (adenosine-5'-monophosphate-activated protein kinase) and MAPK (mitogen activated protein kinase) signaling pathways are noteworthy to activate apoptosis and autophagy ( $\mathrm{Li}$ et al., 2017). Cumulative data by the researchers strongly commend that various chemopreventive agents prompt apoptosis in cancerous cells (Rasul et al., 2012; Rasul et al., 2014).

About 9 derivatives of harmine are reported to have anti-cancer effects in lung and liver cancers (Chen et al., 2005). Overexpression of dual specificity tyrosinephosphorylated and regulated kinase 1A (DYRK1A) has been implicated in an uncontrolled cell proliferation and tumorigenesis. Harmine is an effective inhibitor of protein kinase DYRK1A. Harmine-associated prohibition of DYRK1A triggered apoptosis in human oligodendroglioma (Hs683) cancer cells along with caspase-9 activation (Frederick et al., 2012; Atteya et al., 2017). A harmine derivative, harmine hydrochloride (Har-hc) has been well-known for its anti-cancer potential against glioblastoma C6, U87, and U373 cells with different inhibitory concentrations. Enhanced levels of p21, and Bax while reduced levels of Bcl-2, and Bcl-xl were examined after Har-hc treatment (Liu et al., 2013). Harmine also showed anti-proliferative activity towards thyroid TPC-1 cells via down-regulation of Bcl2 dose-dependently (Ruan et al., 2017).

Harmine, a potent inducer of autophagy and apoptosis displayed multiple anti-proliferative effects on gastric SGC-7901 and MGC-803 cancer cell lines. Attempts were made to investigate apoptosis (mitochondrialmediated, and Akt/mTOR/p70S6K pathway) and autophagy (adenosine 5'-monophosphate-activated protein kinase pathway) affiliated pathways in harmine -treated stomach cancerous cells. Harmine treatment has been linked with the modulation of microtubule protein light chain 3 (LC3-II), Beclin-1, and P62. PI3K/ Akt signaling performs an imperative function in autophagy, DNA repair, apoptosis, cell growth, and translation. A specific combination of $40 \mu \mathrm{M}$ harmine with $10 \mu \mathrm{M}$ LY294002 (inhibitor of PI3K/Akt) enhanced

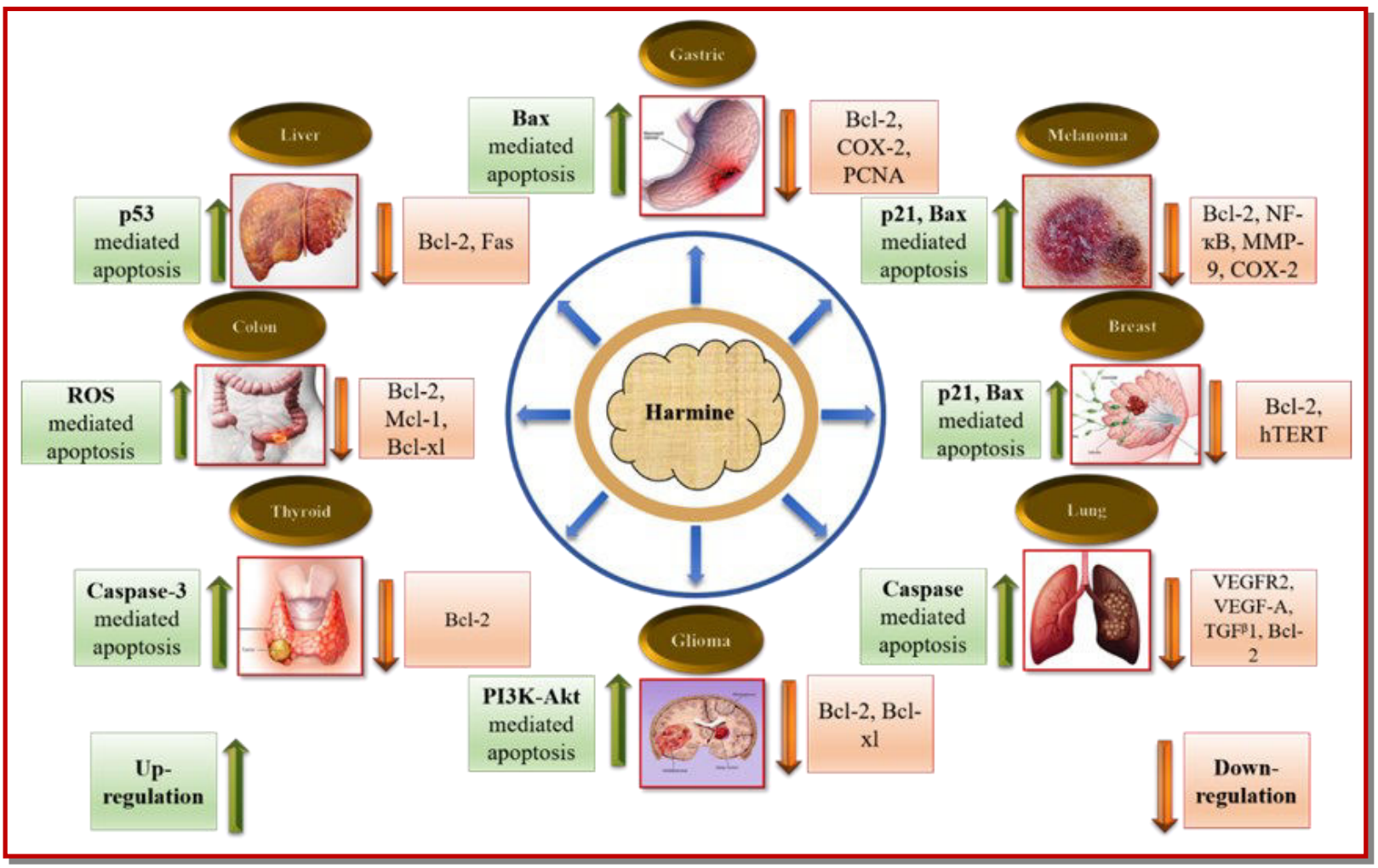

Figure 3: Diagram representing organ-based anti-cancer activity of harmine and its derivatives 
cytotoxicity in gastric cells by up-regulating apoptosisrelated proteins ( $\mathrm{Li}$ et al., 2017). Harmine together with paclitaxel have been reported as the novel drug candidate in numerous cancer types. Harmine and paclitaxel leads to cellular growth inhibition dose-dependently and apoptosis induction in SGC-7901 cells. The cell death mechanism involves activation of Bax while reduced expression of Bcl-2, COX-2, MMP-2, and PCNA expressions (Yu et al., 2016). In BGC-823 gastric cells, harmine $3 c$ compound (benzylidene substituted $\beta$ carboline) exhibited strong apoptotic effect via intracellular ROS production, and suppression of PI3K/Akt pathway (Zhang et al., 2016).

In a study, an optimized harmine derivative, CM16's anti-cancer activity was assessed against oligodendroglioma (Hs683), breast adenocarcinoma (MDA-MB231), and melanoma (SKMEL-28) cell lines. CM16 mainly reduced the translation of neosynthesized proteins in a dose- and concentration-dependent way without affecting mRNA transcription. Moreover, CM16 significantly induced phosphorylation of eukaryotic initiation factor 2 alpha (eIF2a) (Carvalho et al., 2017).

A benzylidene analog of harmine JKA97 has been documented to be a novel drug candidate for breast cancerous cells both in vivo and in vitro. JKA97 dosedependently inhibited proliferation of MDA-MB-468 (p53 mutant), MCF-7 (wild-type), and MCF-7 (p53 knockdown) cells. JKA97 also triggered cellular apoptosis and cell cycle arrest at G1 phase (Yang et al., 2012). In breast MDA-MB-231 cell line, harmine enhanced the expression of $\mathrm{BH} 3$ interacting-domain death agonist (Bid), Bax, TRAIL, caspase-8, and modulator of apoptosis (puma) while Bcl-2 expression was reduced (Bruel et al., 2014; Shabani et al., 2015; Carvalho et al., 2017). Aggregated data indicated that harmine demonstrates pronounced anti-proliferative effects in MCF-7 cells which are associated with the prohibition of telomerase activity. Furthermore, N(9)-acyl derivatives of harmine $11 \mathrm{c}$, and $11 \mathrm{~d}$ with $\mathrm{IC}_{50}$ of $<1 \mu \mathrm{M}$ had displayed remarkable cytotoxic effects against MCF-7 carcinoma cells. The most active derivative of harmine 11d induced apoptosis dose-dependently and caused cell cycle arrest at G2/M phase (Yang et al., 2012; Zhao and Wink 2013; Filali et al., 2015; Du et al., 2016; Filali et al., 2016).

Harmine showed potent anti-metastatic activity against melanoma B16F-10 cells. It also prevented tumor invasion, proliferation and migration in vitro. Further, harmine stimulated apoptosis by activating Bax, caspase-3/-8/-9, and Bid along with decreasing Bcl-2 expression in B16F-10 cells. It also blocked the expression of IL-1 $\beta$, IL-6, and TNF- $\alpha$ which are proinflammatory cytokines (Hamsa and Kuttan, 2011).

Harmine derivative B-9-3 is an angiogenesis inhibitor. It has been reported to possess strong antitumor and angiogenic effects against Lewis lung cancerous cells (LLC). B-9-3 significantly inhibited the growth of vascular fibroblasts, and endothelial cells, and stimulated regression of LLC, human ovary (SKOV-3), prostate (22RV1), and mouse fore-stomach tumor cells. Additionally, B-9-3 elevated apoptotic rate by disrupting VEGF-A/VEGFR2 pathway (Ma et al., 2016). A hybrid of hydroxamic acid and $\beta$-carboline alkaloid harmine exhibited cytotoxicity against lung carcinoma (H460) cells through apoptosis induction associated with the activation of Bax, and down-regulating the Bcl2 expression (Xu et al., 2016), and also known to have protective effects against A549 cancer cells (Filali et al., 2015; Du et al., 2016).

Harmine has the competency to prevent cancer progression in liver Hep3B and Huh-7 cells by inhibiting DYRK1A activity with effective inhibitory concentrations of 10 and $0.25 \mu \mathrm{M}$, respectively (Bruel et al., 2014; Zhang et al., 2015). Harmine has also been proved to be effective against liver HepG2, SMMC7221, and Bel-7402 cells as it can stimulate cellular apoptosis with the activation of Bax, Fas, and caspase$3 /-9$ along with the down-regulating the expression of Bcl-2, and Mcl-1 (Cao et al., 2011).

Harmine and its derivatives have been investigated for their anti-cancer activities against colon HCT-116 cells (Filali et al., 2015; Filali et al., 2016; Xu et al., 2016; Zhang et al., 2016)(Figure 3). In another study, harmine exhibited anti-proliferative effect against colon (Caco2) cancer cells through inhibition of protein kinase DYRK1A (Bruel et al., 2014). Increased expression of Bax, caspase-3 along with PARP cleavage while the decreased activity of Bcl-2, CDK5/p25 and GSK3 $3^{\mathrm{a} / \beta}$ were observed against colorectal RKO, and DLDI cells by harmine treatment (Zhang et al., 2016). Harmine prevented the growth of human SW620 cells in a doserelated manner. The percentage of apoptotic cells was enhanced from 12.0 to $26.4 \%$ when treated with harmine. Results have shown that harmine has the capability to cause cell cycle arrest at G2/M and S phases associated with the increased expression of cyclin A/B1/E2, CDK1/cdc2, p-cdc2 (Tyr15), and Myt1 while decreased expression of cyclin D1. Apoptotic cellular death is accompanied by activation of Bax, PARP, and caspase-3/-9 along with down-regulation of Bcl-2 and Mcl-1 levels. Harmine also inhibited ERK, and Akt pathways in SW620 cells (Liu et al., 2016).

Harmine exerted antitumor effects against bladder EJ cells via up-regulating the expression of Bax and downregulating the expression of Bcl-2 levels (Xu et al., 2016). Harmine derivatives carrying several substituents at position-2, 7 with other $\beta$-carboline rings have played effectual roles in modulating cytotoxic activity against mouth KB cells (Zhang et al., 2016). Harmine together with G-CSF and ATRA inhibited proliferation of leukemia HL-60 cells in the time- and dose-related concentra- 
tions (Zhang et al., 2015).

It can be concluded that harmine derivative $11 \mathrm{~d}$ arrest cell cycle at G2/M phase but whether in G2 or M phase should be investigated. Moreover, it would be interesting to interrogate the mechanism by which harmine derivative JKA97 arrest cell cycle at G0/G1 phase in breast adenocarcinoma cells as in case of other cancer cell lines it is generally arresting cells at G2/M or $S$ phase. So, extensive studies are still obligatory to fully understand the molecular mechanism by which harmine and its derivatives regulate the cell cycle. Furthermore, the exact mechanism of action of harmine in colon (HCT-116), ovary (OVCAR-3), prostate (22RV1), and leukemia (HL-60) cancers has not been fully investigated.

\section{Anti-inflammatory activity}

Various studies have determined that anti-inflammatory activity of natural products are linked with the prohibition of pro-inflammatory mediators and cytokines (TNF-a, iNOS, COX-2), ROS, and transcription factors (NF-kB) (Debnath et al., 2013).

Harmine possesses anti-inflammatory potential as it can inhibit the LPS- and TNF-a-stimulated NF- $\mathrm{KB}$ transactivity in mouse macrophages. It also reduced IL-6, IL$1 \beta$, and TNF- $\alpha$ level respectively (Liu et al., 2017).

$P$. harmala alkaloids including harmine have the competency to block myeloperoxidase activity (MPO), and MPO-mediated LDL-oxidation with $\mathrm{IC}_{50}$ of 0.26 $\mu \mathrm{M}$. Molecular docking analysis indicated that all $P$. harmala alkaloids have great selectivity for the active site of MPO (Bensalem et al., 2014). Harmine has also been reported to suppress TNF-a, IL-6, and NO production in LPS-induced RAW264 macrophages and THP-1 cells of humans in a dose-dependent manner (Yamazaki and Kawano, 2011; Liu et al., 2017) (Table II).

There are only preliminary studies regarding antiinflammatory efficacy of harmine.

\section{Anti-oxidant activity}

Harmine from P. harmala has the capacity to inhibit
$\mathrm{CuSO}_{4}$-mediated LDL oxidation and free radical formation. The anti-oxidant effect of harmine was determined by an increased lag phase time of conjugated dienes, and MDA production. It showed free radical scavenging activity at $10 \mu \mathrm{M}$ concentration (Berrougui et al., 2006). In another study, harmine was found to prohibit lipid peroxidation in enzymatic $\mathrm{Fe}^{3+} \mathrm{ADP}-\mathrm{NADPH}$ and non-enzymatic $\mathrm{Fe}^{3+} \mathrm{ADP}-\mathrm{DHF}$ oxygen radical generating systems in a concentrationdependent way (Tse et al., 1991). Furthermore, harmine along with other $\beta$-carbolines possess protective activity against $\mathrm{H}_{2} \mathrm{O}_{2}$-stimulated oxidative injury in both yeast and mammalian cells (Moura et al., 2007).

1-Methylated $\beta$-carboline (harmine) also has a potential to block SIN-1-induced mitochondrial injury in PC12 cells. The molecular mechanism involves inhibition of apoptotic cell death, and caspase-3/-9 activity via decreasing ROS, and GSH levels (Choi et al., 2004) (Table III). To date, there have been a limited number of studies regarding anti-oxidant, and free radical scavenging activities of harmine. Also, no studies have been done on the anti-oxidant effect of harmine derivatives.

\section{Neuroprotective activity}

The multifarious array of bioactive compounds abundantly found in nature plays an important role in the treatment and prevention of neurodegenerative diseases such as Alzheimer's, Huntington's and other neuronal dysfunctions (Essa et al., 2012). Alkaloids that are isolated from the seeds of TAPH such as harmine exerts the cerebroprotective effect on ethanol-stimulated neurodegeneration and sodium nitrite-stimulated hypoxia in young mice. TAPH eloquently protects the brain from sodium nitrite-induced memory deterioration and retention by reducing the transverse latency time (TLT), and enhancing step down latency (SDL) in a dose-related manner. It also inhibits acetylcholinesterase activity, protects DNA fragmentation, upregulates GSH level, and down-regulates TBARS expression in brain (Biradar et al., 2013).

Preclinical studies on harmine have suggested that it exhibits the neuroprotective effect in a rat model of

Table II

Molecular targets of anti-inflammatory activities of harmine

\begin{tabular}{|c|c|c|c|c|}
\hline Assay & Organism tested & Dose/conc. & Molecular targets & References \\
\hline $\begin{array}{l}\text { Evaluation of anti-inflammatory effect of } \\
\text { isoxazoline derivatives from harmine }\end{array}$ & $\begin{array}{l}\text { Mouse macrophages } \\
\text { (RAW264 cells) }\end{array}$ & $29.2,55.5 \mu \mathrm{M}$ & - & Filali et al., 2015 \\
\hline $\begin{array}{l}\text { Anti-inflammatory effects of harmine on } \\
\text { myeloperoxidase activity }\end{array}$ & - & $0.26 \mu \mathrm{M}$ & - & $\begin{array}{l}\text { Bensalem et al., } \\
2014\end{array}$ \\
\hline $\begin{array}{l}\text { Anti-inflammatory effects of harmine in } \\
\text { RAW264 macrophages and THP-1 cells }\end{array}$ & $\begin{array}{l}\text { Mouse RAW264 cells, } \\
\text { Human THP-1 cells }\end{array}$ & $\begin{array}{l}4,10,2.1,0.02, \\
8 \mu \mathrm{M}\end{array}$ & $\begin{array}{l}\text { IL-6 } \downarrow \text {, TNF- } \mathrm{a} \downarrow \text {, } \\
\text { NO } \downarrow \text {, }\end{array}$ & $\begin{array}{l}\text { Yamazaki and } \\
\text { Kawano, } 2011\end{array}$ \\
\hline $\begin{array}{l}\text { In vitro anti-inflammatory effects of } \\
\text { harmine }\end{array}$ & $\begin{array}{l}\text { Mouse } \\
\text { (RAW264 cells) }\end{array}$ & - & $\begin{array}{l}\text { TNF- } \alpha \downarrow \text {, } \\
\text { IL-1 } \beta \downarrow, \text { IL-6 } \downarrow \text {, NF- } \\
\mathrm{\kappa B}^{\perp}\end{array}$ & Liu et al., 2017 \\
\hline
\end{tabular}


Table III

Molecular targets of anti-oxidant function of harmine

\begin{tabular}{|llllll|}
\hline Assay & Organism tested & Dose/conc. & Mechanisms & References \\
\hline $\begin{array}{l}\text { Anti-oxidant effect of harmine on CuSO4- } \\
\text { stimulated LDL oxidation }\end{array}$ & - & $10 \mu \mathrm{M}$ & $\begin{array}{l}\text { Decrease in a- } \\
\text { tocopherol level }\end{array}$ & $\begin{array}{l}\text { Berrougui et al., } \\
2006\end{array}$ \\
$\begin{array}{l}\text { Anti-oxidant effect of harmine on lipid } \\
\text { peroxidation }\end{array}$ & Sprague Dawley rats \\
$\begin{array}{l}\text { Defensive effects of harmine against } \mathrm{H}_{2} \mathrm{O}_{2-}- \\
\text { induced oxidative damage }\end{array}$ & $\begin{array}{l}\text { WT cells, isogenic } \\
\text { mutant strains of } \\
\text { S. cerevisiae }\end{array}$ & $\begin{array}{l}0.5-150 \mu \mathrm{g} / \mathrm{mL} \\
\mathrm{mL}\end{array}$ & - & Tse et al., 1991 \\
$\begin{array}{l}\text { Defensive potential of 1-methylated } \beta- \\
\text { carboline (harmine) against 3-morpholino- } \\
\text { sydnonimine-mediated mitochondrial } \\
\text { damage }\end{array}$ & & - & - & Moura et al., 2007 \\
\hline
\end{tabular}

sclerosis via increasing the activity of glutamate transporter-1 (GLT-1), and decreasing TNF- $\alpha$, IL-1 $\beta$ levels in the hippocampus. Further, post-GCl harmine administration has the ability to debilitate cerebral infarct volume, and to reduce neuronal cell death in vivo (Li et al., 2011; Sun et al., 2014). Some recent experimentation showed that continuous usage of ayahuasca (harminerich hallucinogen) is linked with improved neuropsychological functioning. Moreover, harmine treatment reduced inflammation, excitotoxicity and, oxidative stress along with enhanced levels of neurotrophic factors (BDNF), and glutamate transporters in the hippocampus (Dos Santos and Hallak, 2017).

\section{Antidepressant activity}

Various studies in animals have shown that ayahuasca and harmine possess antidepressant-like effects in the behavioral animal model of depression. Harmine and tetrahydroharmine encouraged adult neurogenesis and stimulated neural stem cell growth, migration, and differentiation in vitro (Morales-Garcia et al., 2017). Furthermore, acute and chronic administration of harmine at high dosage $(5,10,15 \mathrm{mg} / \mathrm{kg})$ demonstrated behavioral and physiological effects by elevating SOD, CAT, BDNF and ACTH circulation levels in a rat model of hippocampus and prefrontal cortex (Fortunato et al., 2009; Fortunato et al., 2010a; Fortunato et al., 2010b; Reus et al., 2010). In another investigation, harmine significantly increased the proliferation in human neural progenitor cells and blocked DYRK1A activity, respectively (Dakic et al., 2016).

Harmine has also been known as a modulator of astrocytic glutamate transporters on CUS-stimulated astrocytic dysfunctions and depressive behaviors. Harmine treatment $(20 \mathrm{mg} / \mathrm{kg})$ improved BDNF expression on hippocampal neurogenesis and up-regulated GLT-1 activity (Liu et al., 2017). Accumulated data by the researchers acclaim that inhibition of monoamineoxidase A (MAO-A) is associated with antidepressant efficacy of harmine (Chiuccariello et al., 2015; Sacher et al., 2015; Balint et al., 2017; Hamid et al., 2017; Li et al., 2017; Meyer, 2017). Harmine (300 nM) was also reported to augment dopamine efflux by an innovative and 5 -HT(2A) receptor-dependent mechanism (Brierley and Davidson, 2013).

\section{Anti-microbial activity}

Harmine its various synthetic derivatives are known to possess anti-microbial effects against different fungal species such as Fusarium oxysporum, Colletotrichum gloeosporioides (Salman et al., 2016). Harmine exerted a noticeable prohibitory effect on germination of conidia at the concentration between 0.5 to $1 \mathrm{mM}$. In another study, harmine showed fungicidal activity (>60\%) against Physalospora piricola at $50 \mathrm{mg} / \mathrm{kg}$ concentration (Olmedo et al., 2017).

Furthermore, harmine and its derivatives have antiviral activities against tobacco mosaic virus as well as anti-fungal effects against Puccinia sorghi (Lu et al., 2015). Harmine has been found to prohibit HSV infection at $\mathrm{CC}_{50}$ value around $337.1 \mu \mathrm{M}$ and, $\mathrm{EC}_{50}$ value of $1.5 \mu \mathrm{M}$ in a dose-dependent way. Harmine significantly down-regulated HSV-2-mediated activation of NF-KB along with p65 nuclear translocation, and IкB- $\alpha$ degeneration. It also blocked HSV-2-induced JNK phosphorylation and p38 MAPK kinase activity, respectively (Chen et al., 2016). Moreover, a synthetic derivative of harmine, $9 \mathrm{~N}$-methylharmine demonstrates a strong inhibitory effect on DENV-2 generation. The quantification of extracellular and intracellular viral genomes designated that $9 \mathrm{~N}$-methylharmine has capability to debilitate maturation time and discharge of viral entities to the extracellular medium influencing the transmission of the disease (Quintana et al., 2016).

The study of harmine's anti-viral mode of action indicated that it eloquently prohibits enterovirus (EV71) via targeting NF-кB signaling pathway with $\mathrm{CC}_{50}$ value of $500 \mu \mathrm{M}$ and, $\mathrm{EC}_{50}$ value of $20 \mu \mathrm{M}$ in vitro. The associated mechanism involves decreased ROS produc- 
tion, and suppressed EV71-prompted NF-kB activation. Additionally, harmine treatment has a potential to defend AG129 mice against EV71 replication in vivo (Quintana et al., 2016; Chen et al., 2018).

\section{Other biological activities of harmine}

Harmine has also been known to possess several other biological activities. Primitive studies have declared that harmine is an auspicious anti-malarial agent selectively targeting P. falciparum PfHsp90. The unique and non-toxic harmine analogues $17 \mathrm{~A}$ and $21 \mathrm{~A}$ have the affinity to bind with heat shock protein-90, inhibits $P$. falciparum at concentration of $4.2 \pm 1.3 \mu \mathrm{M}$ and $5.7 \pm 1.7$ $\mu \mathrm{M}$ during in vitro investigation, decreases parasitaemia and extends survival of $P$. berghei-affected BALB/c mice (100 mg/kg) in vivo (Bayih et al., 2016).

Harmine has the competency to block multinucleated bone resorption and osteoclast differentiation both in vivo and in vitro. In MC3T3-E1 cells, harmine actively induced alkaline phosphatase activity without affecting their growth. Harmine significantly up-regulates mRNA levels of Bmp-2/-4/-6/-7, Runx2, Osterix, as well as its target genes $1 \mathrm{~d} 1$ and $1 \mathrm{~d} 2$. In another investigation, harmine treatment $(10 \mathrm{mg} / \mathrm{kg} /$ day $)$ prevented osteoclast production by RANKL-stimulated bone resorption via reducing the expression of NFATc1 (a key regulator of osteoclastogenesis), c-Fos respectively (Egusa et al., 2011; Yonezawa et al., 2011). Further, the chondroprotective effect of harmine was examined under inflammatory situation by induction with TNF-a. Results showed that in human HCS-2/8 cells, harmine is capable to attenuate TNF-a-stimulated reduction in the expression and activity of cartilage markers (COL2a1, aggrecan) and CCN2 (Egusa et al., 2011).

Harmine is efficiently utilized in biotechnological fields (Rasse-Suriani et al., 2018) with some more bioactivities including anti-mutagenic, and anti-genotoxic (Patel et al., 2012).

Harmine along with other alkaloids have shown antileishmanial activity against Leishmania infantum (with both forms of parasites e.g. amastigote and promastigote) in vivo in hamster models (Dai et al., 2012). Harmine acts as an anti-toxoplasmic agent against Toxoplasma gondii (Alomar et al., 2013), as a photosensitizer (Vignoni et al., 2013) and also as an anti-trichomonal agent against T. gallinae (Tabari et al., 2017).

\section{Conclusion}

Harmine is a potent drug candidate and its synthetic derivatives exhibit pharmacological and biological effects in various ailments through diversified mechanisms of action. Pharmacodynamically and pharmacokinetically up-graded harmine and its derivatives may also boost up further advances. This review has emphasized on recent researches from various in vivo and in vitro investigations on the ability of harmine and its derivatives to cure different pathological conditions.

\section{Conflict of Interest}

Authors declare that no conflicts of interest exist.

\section{Acknowledgement}

This study was supported by the research grants from the TWAS-COMSTECH (no.17-180 RG/PHA/AS_C) and The Nagai Foundation Tokyo, Japan (NFT-R4-2017 and NFT-R2018). The authors would also like to thank Higher Education Commission (HEC), Pakistan, for providing access to related papers from various journals.

\section{References}

Alomar ML, Rasse-Suriani FA, Ganuza A, Coceres VM, Cabrerizo FM, Angel SO. In vitro evaluation of beta-carboline alkaloids as potential anti-Toxoplasma agents. BMC Res Notes. 2013; 6: 193.

Arora D, Rani A, Sharma A. A review on phytochemistry and ethnopharmacological aspects of genus Calendula. Pharmacogn Rev. 2013; 7: 179-87.

Atteya R, Ashour ME, Ibrahim EE, Farag MA, El-Khamisy SF. Chemical screening identifies the beta-carboline alkaloid harmine to be synergistically lethal with doxorubicin. Mech Ageing Dev. 2017; 161: 141-48.

Bais $\mathrm{PH}$, Vepachedu R, Vivanco MJ. Root specific elicitation and exudation of fluorescent $\beta$-carbolines in transformed root cultures of Oxalis tuberosa. Plant Physiol Biochem. 2003; 41: 345-53.

Balint B, Weber C, Cruzalegui F, Burbridge M, Kotschy A. Structure-based design and synthesis of harmine derivatives with different selectivity profiles in kinase versus monoamine oxidase inhibition. Chem Med Chem. 2017; 12: 932-39.

Bayih AG, Folefoc A, Mohon AN, Eagon S, Anderson M, Pillai DR. In vitro and in vivo anti-malarial activity of novel harmine-analog heat shock protein 90 inhibitors: A possible partner for artemisinin. Malar J. 2016; 15: 579.

Bensalem S, Soubhye J, Aldib I, Bournine L, Nguyen AT, Vanhaeverbeek M, Rousseau A, Boudjeltia KZ, Sarakbi A, Kauffmann JM, Neve J, Prevost M, Stevigny C, MaizaBenabdesselam F, Bedjou F, Van Antwerpen P, Duez P. Inhibition of myeloperoxidase activity by the alkaloids of Peganum harmala L. (Zygophyllaceae). J Ethnopharmacol. 2014; 154: 361-69.

Berrougui H, Isabelle M, Cloutier M, Hmamouchi M, Khalil A. Protective effects of Peganum harmala L. extract, harmine and harmaline against human low-density lipoprotein oxidation. J Pharm Pharmacol. 2006; 58: 967-74.

Biradar SM, Joshi H, Tarak KC. Cerebroprotective effect of isolated harmine alkaloids extracts of seeds of Peganum harmala L. on sodium nitrite-induced hypoxia and ethanol- 
induced neurodegeneration in young mice. Pakistan J Biol Sci. 2013; 16: 1687-97.

Bouayad N, Rharrabe K, Lamhamdi M, Nourouti NG, Sayah F. Dietary effects of harmine, a beta-carboline alkaloid, on development, energy reserves and alpha-amylase activity of Plodia interpunctella Hubner (Lepidoptera: Pyralidae). Saudi J Biol Sci. 2012; 19: 73-80.

Brierley DI, Davidson C. Harmine augments electrically evoked dopamine efflux in the nucleus accumbens shell. J Psychopharmacol. 2013; 27: 98-108.

Bruel A, Beneteau R, Chabanne M, Lozach O, Le Guevel R, Ravache M, Benedetti H, Meijer L, Loge C, Robert JM. Synthesis of new pyridazino[4,5-b]indol-4-ones and pyridazin-3(2H)-one analogs as DYRK1A inhibitors. Bioorg Med Chem Lett. 2014; 24: 5037-40.

Cao MR, Li Q, Liu ZL, Liu HH, Wang W, Liao XL, Pan YL, Jiang JW. Harmine induces apoptosis in HepG2 cells via mitochondrial signaling pathway. Hepatobiliary Pancreat Dis Int. 2011; 10: 599-604.

Cao R, Fan W, Guo L, Ma Q, Zhang G, Li J, Chen X, Ren Z, Qiu L. Synthesis and structure-activity relationships of harmine derivatives as potential antitumor agents. Eur J Med Chem. 2013; 60: 135-43.

Carvalho A, Chu J, Meinguet C, Kiss R, Vandenbussche G, Masereel B, Wouters J, Kornienko A, Pelletier J, Mathieu V. A harmine-derived beta-carboline displays anti-cancer effects in vitro by targeting protein synthesis. Eur J Pharmacol. 2017; 805: 25-35.

Chen D, Tian X, Zou X, Xu S, Wang H, Zheng N, Wu Z. Harmine, a small molecule derived from natural sources, inhibits enterovirus 71 replication by targeting NF-kappaB pathway. Int Immunopharmacol. 2018; 60: 111-20.

Chen L, Xie J, Song H, Liu Y, Gu Y, Wang L, Wang Q. Design, Synthesis, and biological activities of spirooxindoles containing acylhydrazone fragment derivatives based on the biosynthesis of alkaloids derived from tryptophan. J Agric Food Chem. 2016; 64: 6508-16.

Chen Q, Chao R, Chen H, Hou X, Yan H, Zhou S, Peng W, Xu A. Antitumor and neurotoxic effects of novel harmine derivatives and structure-activity relationship analysis. Int J Cancer. 2005; 114: 675-82.

Chiuccariello L, Cooke RG, Miler L, Levitan RD, Baker GB, Kish SJ, Kolla NJ, Rusjan PM, Houle S, Wilson AA, Meyer $\mathrm{JH}$. Monoamine oxidase-A occupancy by moclobemide and phenelzine: Implications for the development of monoamine oxidase inhibitors. Int J Neuropsychopharmacol. 2015; 19:

Choi WT, Youn YC, Han ES, Lee CS. Protective effect of 1methylated beta-carbolines against 3-morpholinosydnonimine-induced mitochondrial damage and cell viability loss in PC12 cells. Neurochem Res. 2004; 29: 1807-16.

Dai F, Chen Y, Song Y, Huang L, Zhai D, Dong Y, Lai L, Zhang T, Li D, Pang X, Liu M, Yi Z. A natural small molecule harmine inhibits angiogenesis and suppresses tumour growth through activation of p53 in endothelial cells. PLoS One. 2012; 7: e52162.

Dakic V, Maciel RM, Drummond H, Nascimento JM, Trindade $\mathrm{P}$, Rehen SK. Harmine stimulates proliferation of human neural progenitors. Peer J. 2016; 4: e2727.
Debnath T, Kim DH, Lim BO. Natural products as a source of anti-inflammatory agents associated with inflammatory bowel disease. Molecules 2013; 18: 7253-70.

Dos Santos RG, Hallak JE. Effects of the natural beta-carboline alkaloid harmine, a main constituent of ayahuasca, in memory and in the hippocampus: A systematic literature review of preclinical studies. J Psychoactive Drugs. 2017; 49: $1-10$.

Du H, Tian S, Chen J, Gu H, Li N, Wang J. Synthesis and biological evaluation of $\mathrm{N}(9)$-substituted harmine derivatives as potential anticancer agents. Bioorg Med Chem Lett. 2016; 26: 4015-19.

Egusa H, Doi M, Saeki M, Fukuyasu S, Akashi Y, Yokota Y, Yatani $\mathrm{H}$, Kamisaki $Y$. The small molecule harmine regulates NFATc1 and Id2 expression in osteoclast progenitor cells. Bone 2011; 49: 264-74.

Essa MM, Vijayan RK, Castellano-Gonzalez G, Memon MA, Braidy N, Guillemin GJ. Neuroprotective effect of natural products against Alzheimer's disease. Neurochem Res. 2012; 37: 1829-42.

Filali I, Bouajila J, Znati M, Bousejra-El Garah F, Ben Jannet H. Synthesis of new isoxazoline derivatives from harmine and evaluation of their anti-Alzheimer, anti-cancer and antiinflammatory activities. J Enzyme Inhib Med Chem. 2015; 30: 371-76.

Filali I, Romdhane A, Znati M, Jannet HB, Bouajila J. Synthesis of new harmine isoxazoles and evaluation of their potential anti-Alzheimer, anti-inflammatory, and anti-cancer activities. Med Chem. 2016; 12: 184-90.

Fortunato JJ, Reus GZ, Kirsch TR, Stringari RB, Fries GR, Kapczinski F, Hallak JE, Zuardi AW, Crippa JA, Quevedo J. Chronic administration of harmine elicits antidepressant-like effects and increases BDNF levels in rat hippocampus. J Neural Transm (Vienna). 2010a; 117: 1131-37.

Fortunato JJ, Reus GZ, Kirsch TR, Stringari RB, Fries GR, Kapczinski F, Hallak JE, Zuardi AW, Crippa JA, Quevedo J. Effects of beta-carboline harmine on behavioral and physiological parameters observed in the chronic mild stress model: Further evidence of antidepressant properties. Brain Res Bull. 2010b; 81: 491-96.

Fortunato JJ, Reus GZ, Kirsch TR, Stringari RB, Stertz L, Kapczinski F, Pinto JP, Hallak JE, Zuardi AW, Crippa JA, Quevedo J. Acute harmine administration induces antidepressive-like effects and increases BDNF levels in the rat hippocampus. Prog Neuropsychopharmacol Biol Psychiatry. 2009; 33: 1425-30.

Frederick R, Bruyere C, Vancraeynest C, Reniers J, Meinguet C, Pochet L, Backlund A, Masereel B, Kiss R, Wouters J. Novel trisubstituted harmine derivatives with original in vitro anticancer activity. J Med Chem. 2012; 55: 6489-501.

Fyre A, Haustein C. Extraction, identification, and quantification of harmala alkaloids in three species of Passiflora. AJUR. 2007; 6: 19-26.

Gurib-Fakim A. Medicinal plants: Traditions of yesterday and drugs of tomorrow. Mol Aspects Med. 2006; 27: 1-93.

Hamid HA, Ramli AN, Yusoff MM. Indole alkaloids from plants as potential leads for antidepressant drugs: A mini review. Front Pharmacol. 2017; 8: 96. 
Hamsa TP, Kuttan G. Harmine activates intrinsic and extrinsic pathways of apoptosis in B16F-10 melanoma. Chin Med. 2011; 6: 11.

Hara ES, Ono M, Kubota S, Sonoyama W, Oida Y, Hattori T, Nishida T, Furumatsu T, Ozaki T, Takigawa M, Kuboki T. Novel chondrogenic and chondroprotective effects of the natural compound harmine. Biochimie 2013; 95: 374-81.

Harvey AL, Edrada-Ebel R, Quinn RJ. The re-emergence of natural products for drug discovery in the genomics era. Nat Rev Drug Discov. 2015; 14: 111-29.

Herraiz T. Evaluation of the oxidation of 1-methyl-4-phenyl1,2,3,6-tetrahydropyridine (MPTP) to toxic pyridinium cations by monoamine oxidase (MAO) enzymes and its use to search for new MAO inhibitors and protective agents. J Enzyme Inhib Med Chem. 2012; 27: 810-17.

Kurzawa M, Filipiak-Szok A, Klodzinska E, Szlyk E. Determination of phytochemicals, anti-oxidant activity and total phenolic content in Andrographis paniculata using chromatographic methods. J Chromatogr B. 2015; 995: 101-06.

Lamchouri F, Toufik H, Elmalki Z, Bouzzine S, Malek HA, Hamidi M, Bouachrine M. Quantitative structure-activity relationship of antitumor and neurotoxic $\beta$-carbolines alkaloids: Nine harmine derivatives. Res Chem Intermediat. 2013; 39: 2219-36.

Li C, Wang Y, Wang C, Yi X, Li M, He X. Anti-cancer activities of harmine by inducing a pro-death autophagy and apoptosis in human gastric cancer cells. Phytomedicine 2017; 28: 10-18.

Li S, Wang A, Gu F, Wang Z, Tian C, Qian Z, Tang L, Gu Y. Novel harmine derivatives for tumor targeted therapy. Oncotarget 2015; 6: 8988-9001.

Li S, Zhang Y, Deng G, Wang Y, Qi S, Cheng X, Ma Y, Xie Y, Wang C. Exposure characteristics of the analogous betacarboline alkaloids harmaline and harmine based on the efflux transporter of multidrug resistance protein 2. Front Pharmacol. 2017; 8: 541.

Li Y, Sattler R, Yang EJ, Nunes A, Ayukawa Y, Akhtar S, Ji G, Zhang PW, Rothstein JD. Harmine, a natural beta-carboline alkaloid, upregulates astroglial glutamate transporter expression. Neuropharmacology 2011; 60: 1168-75.

Liu B. Study on chemical constituents of Peganum multisectum. Zhong Yao Cai. 2011; 34: 1719-21.

Liu F, Wu J, Gong Y, Wang P, Zhu L, Tong L, Chen X, Ling Y, Huang $C$. Harmine produces antidepressant-like effects via restoration of astrocytic functions. Prog Neuropsychopharmacol Biol Psychiatry. 2017; 79: 258-67.

Liu H, Han D, Liu Y, Hou X, Wu J, Li H, Yang J, Shen C, Yang G, Fu C, Li X, Che H, Ai J, Zhao S. Harmine hydrochloride inhibits Akt phosphorylation and depletes the pool of cancer stem-like cells of glioblastoma. J Neurooncol. 2013; 112: 3948.

Liu J, Li Q, Liu Z, Lin L, Zhang X, Cao M, Jiang J. Harmine induces cell cycle arrest and mitochondrial pathwaymediated cellular apoptosis in SW620 cells via inhibition of the Akt and ERK signaling pathways. Oncol Rep. 2016; 35: 3363-70.

Liu X, Li M, Tan S, Wang C, Fan S, Huang C. Harmine is an inflammatory inhibitor through the suppression of NF-
kappaB signaling. Biochem Biophys Res Commun. 2017; 489: 332-38.

Lu A, Ma Y, Wang Z, Zhou Z, Wang Q. Application of "Hydrogen-Bonding Interaction" in Drug Design. Part 2: Design, synthesis, and structure-activity relationships of thiophosphoramide derivatives as novel antiviral and antifungal agents. J Agric Food Chem. 2015; 63: 9435-40.

Luo W, Liu J, Li J, Zhang D, Liu M, Addo JK, Patil S, Zhang L, Yu J, Buolamwini JK, Chen J, Huang C. Anti-cancer effects of JKA97 are associated with its induction of cell apoptosis via a Bax-dependent and p53-independent pathway. J Biol Chem. 2008; 283: 8624-33.

Luo Y, Cobb RE, Zhao H. Recent advances in natural product discovery. Curr Opin Biotechnol. 2014; 30: 230-37.

Ma Q, Chen W, Chen W. Anti-tumor angiogenesis effect of a new compound: B-9-3 through interference with VEGFR2 signaling. Tumour Biol. 2016; 37: 6107-16.

Ma ZZ, Hano Y, Nomura T, Chen YJ. Alkaloids and phenylpropanoids from Peganum nigellastrum. Phytochemistry 2000; 53: 1075-78.

Meyer JH. Neuroprogression and immune activation in major depressive disorder. Mod Trends Pharmacopsychiatry. 2017; 31: 27-36.

Mohammad RM, Muqbil I, Lowe L, Yedjou C, Hsu HY, Lin LT, Siegelin MD, Fimognari C, Kumar NB, Dou QP, Yang H, Samadi AK, Russo GL, Spagnuolo C, Ray SK, Chakrabarti M, Morre JD, Coley HM, Honoki K, Fujii H, Georgakilas AG, Amedei A, Niccolai E, Amin A, Ashraf SS, Helferich WG, Yang X, Boosani CS, Guha G, Bhakta D, Ciriolo MR, Aquilano K, Chen S, Mohammed SI, Keith WN, Bilsland A, Halicka D, Nowsheen S, Azmi AS. Broad targeting of resistance to apoptosis in cancer. Semin Cancer Biol. 2015; 35 Suppl: S78-S103.

Morales-Garcia JA, de la Fuente Revenga M, Alonso-Gil S, Rodriguez-Franco MI, Feilding A, Perez-Castillo A, Riba J. The alkaloids of Banisteriopsis caapi, the plant source of the Amazonian hallucinogen Ayahuasca, stimulate adult neurogenesis in vitro. Sci Rep. 2017; 7: 5309.

Moura DJ, Richter MF, Boeira JM, Pegas Henriques JA, Saffi J. Anti-oxidant properties of beta-carboline alkaloids are related to their antimutagenic and antigenotoxic activities. Mutagenesis. 2007; 22: 293-302.

Newman DJ, Cragg GM, Snader KM. Natural products as sources of new drugs over the period 1981-2002. J Nat Prod. 2003; 66: 1022-37.

Olmedo GM, Cerioni L, Gonzalez MM, Cabrerizo FM, Rapisarda VA, Volentini SI. Antifungal activity of beta-carbolines on Penicillium digitatum and Botrytis cinerea. Food Microbiol. 2017; 62: 9-14.

Patel K, Gadewar M, Tripathi R, Prasad SK, Patel DK. A review on medicinal importance, pharmacological activity and bioanalytical aspects of beta-carboline alkaloid harmine. Asian Pac J Trop Biomed. 2012; 2: 660-64.

Quintana VM, Piccini LE, Panozzo Zenere JD, Damonte EB, Ponce MA, Castilla V. Antiviral activity of natural and synthetic beta-carbolines against dengue virus. Antiviral Res. 2016; 134: 26-33.

Rasse-Suriani FA, García-Einschlag FS, Rafti M, Schmidt De 
Leon T, David Gara PM, Erra-Balsells R, Cabrerizo FM. Photophysical and photochemical properties of naturally occurring normelinonine $\mathrm{F}$ and melinonine $\mathrm{F}$ alkaloids and structurally related N(2)- and/or N(9)-methyl-beta-carboline derivatives. Photochem Photobiol. 2018; 94: 36-51.

Rasul A, Millimouno FM, Ali Eltayb W, Ali M, Li J, Li X. Pinocembrin: A novel natural compound with versatile pharmacological and biological activities. Biomed Res Int. 2013; 2013.

Rasul A, Yu B, Zhong L, Khan M, Yang H, Ma T. Cytotoxic effect of evodiamine in SGC-7901 human gastric adenocarcinoma cells via simultaneous induction of apoptosis and autophagy. Oncol Rep. 2012; 27: 1481-87.

Rasul A, Zhao BJ, Liu J, Liu B, Sun JX, Li J, Li XM. Molecular mechanisms of casticin action: An update on its antitumor functions. Asian Pac J Cancer Prev. 2014; 15: 9049-58.

Reus GZ, Stringari RB, de Souza B, Petronilho F, Dal-Pizzol F, Hallak JE, Zuardi AW, Crippa JA, Quevedo J. Harmine and imipramine promote anti-oxidant activities in prefrontal cortex and hippocampus. Oxid Med Cell Longev. 2010; 3: 325-31.

Ruan S, Jia F, Li J. Potential antitumor effect of harmine in the treatment of thyroid cancer. Evid Based Complement Alternat Med. 2017; 2017.

Sacher J, Rekkas PV, Wilson AA, Houle S, Romano L, Hamidi J, Rusjan P, Fan I, Stewart DE, Meyer JH. Relationship of monoamine oxidase: A distribution volume to postpartum depression and postpartum crying. Neuropsychopharmacology 2015; 40: 429-35.

Salman S, Idrees F, Pervaiz S, Shah FH, Badshah S, Abdullah, Usman M, Halimi SA, Idrees J. Short communication: Evaluation of antimicrobial activities of harmine, harmaline, nicotine and their complexes. Pakistan J Pharm Sci. 2016; 29: 1317-20.

Sarfraz I, Rasul A, Jabeen F, Younis T, Zahoor MK, Arshad M, Ali M. Fraxinus: A plant with versatile pharmacological and biological activities. Evid Based Complement Alternat Med. 2017; 2017: 4269868

Shabani SH, Tehrani SS, Rabiei Z, Enferadi ST, Vannozzi GP. Peganum harmala L.'s anti-growth effect on a breast cancer cell line. Biotechnol Rep. 2015; 8: 138-43.

Sun P, Zhang S, Li Y, Wang L. Harmine mediated neuroprotection via evaluation of glutamate transporter 1 in a rat model of global cerebral ischemia. Neurosci Lett. 2014; 583: 32-36.

Tabari MA, Youssefi MR, Moghadamnia AA. Antitrichomonal activity of Peganum harmala alkaloid extract against trichomoniasis in pigeon (Columba livia domestica). Br Poult Sci. 2017; 58: 236-41.

Taylor PW. Alternative natural sources for a new generation of antibacterial agents. Int J Antimicrob Agents. 2013; 42: 195201.
Tse SY, Mak IT, Dickens BF. Anti-oxidative properties of harmane and beta-carboline alkaloids. Biochem Pharmacol. 1991; 42: 459-64.

Vignoni M, Rasse-Suriani FA, Butzbach K, Erra-Balsells R, Epe B, Cabrerizo FM. Mechanisms of DNA damage by photoexcited 9-methyl-beta-carbolines. Org Biomol Chem. 2013; 11: 5300-09.

Westcott DN, Hinks CF, Olrfert O. Dietary effects of secondary plant compounds on nymphs of Melanoplus sanguinipes (Orthoptera: Acrididae). Ann Entomol Soc Am. 1992; 85: 30409.

Xu QB, Chen XF, Feng J, Miao JF, Liu J, Liu FT, Niu BX, Cai JY, Huang $C$, Zhang Y, Ling Y. Design, synthesis and biological evaluation of hybrids of beta-carboline and salicylic acid as potential anti-cancer and apoptosis inducing agents. Sci Rep. 2016; 6: 36238

Yamazaki Y, Kawano Y. Inhibitory effects of herbal alkaloids on the tumor necrosis factor-alpha and nitric oxide production in lipopolysaccharide-stimulated RAW264 macrophages. Chem Pharm Bull (Tokyo). 2011; 59: 388-91.

Yang X, Wang W, Qin JJ, Wang MH, Sharma H, Buolamwini JK, Wang H, Zhang R. JKA97, a novel benzylidene analog of harmine, exerts anti-cancer effects by inducing G1 arrest, apoptosis, and p53-independent up-regulation of p21. PLoS One. 2012; 7: e34303.

Yonezawa T, Hasegawa S, Asai M, Ninomiya T, Sasaki T, Cha BY, Teruya T, Ozawa H, Yagasaki K, Nagai K, Woo JT. Harmine, a beta-carboline alkaloid, inhibits osteoclast differentiation and bone resorption in vitro and in vivo. Eur J Pharmacol. 2011; 650: 511-18.

Yu XJ, Sun K, Tang XH, Zhou CJ, Sun H, Yan Z, Fang L, Wu HW, Xie YK, Gu B. Harmine combined with paclitaxel inhibits tumor proliferation and induces apoptosis through down-regulation of cyclooxygenase- 2 expression in gastric cancer. Oncol Lett. 2016; 12: 983-88.

Zhang L, Zhang F, Zhang W, Chen L, Gao N, Men Y, Xu X, Jiang $\mathrm{Y}$. Harmine suppresses homologous recombination repair and inhibits proliferation of hepatoma cells. Cancer Biol Ther. 2015; 16: 1585-92.

Zhang XF, Sun RQ, Jia YF, Chen Q, Tu RF, Li KK, Zhang XD, $\mathrm{Du}$ RL, Cao RH. Synthesis and mechanisms of action of novel harmine derivatives as potential antitumor agents. Sci Rep. 2016; 6: 33204.

Zhao L, Wink M. The beta-carboline alkaloid harmine inhibits telomerase activity of MCF-7 cells by down-regulating hTERT mRNA expression accompanied by an accelerated senescent phenotype. PeerJ. 2013; 1: e174.

Zhao T, He YQ, Wang J, Ding KM, Wang $\mathrm{CH}$, Wang ZT. Inhibition of human cytochrome P450 enzymes 3A4 and 2D6 by beta-carboline alkaloids, harmine derivatives. Phytother Res. 2011; 25: 1671-77. 